\title{
当科入院症例における感染症の実状
}

\author{
長崎大学医学部整形外科 \\ 古川泰之・乗 松敏 晴 \\ 原真一郎・鈴 木 良平
}

\section{Experience of non-Tubercular Osteomyelitis and Pyogenic Arthritis in our Hospital}

by

Hiroyuki Furukawa, Toshiharu Norimatsu, Shinichiro Hara and Ryohei Suzuki

Department of Orthopaedic Surgery Nagasaki University

School of Medicine

Forty-nine patients who were hospitalized in Nagasaki University between February, 1977 and July, 1985, were examined in order to know the trend about the bacterial infections of bones and joints.

Most of the bacillus in 37 cases of osteomyelitis and in 12 cases of pyogenic arthritis were staphylococcus aureus. There was a tendency of increase of the subacute and chronic types of osteomyelitis, and the pyogenic arthritis which was followed by puncture of the knee joint. Our results suggested that while diagnosing the osteomyelitis, the recognition of the existence of the subacute osteomyelitis is very important, and that we must pay more attention to prevent the iatrogenic infection.

\section{はじめに}

感染症は, 近年グラム陰性桿菌感染の増加, 而性菌 の出現, 日和見感染の増加などのように病態が変化し てきたとされる. 整形外科領域においても当然そのよ うな変化がみられ，診断や，治療においても，それな りの対応が必要と思われる.

今回は, このような感染症の病態の変化をふまえて 当科における感染症の実状を調査したので報告する.

\section{対象および方法}

当病院が現在の建物になった昭和 52 年 2 月から, 昭 和 60 年 7 月までに, 当科に入院した感染症は, 表 1 に 示すごとくで, 全入院患者数の $2.2 \%$ を占める. 今回 検索の対象としたのは, 非結核性 58 例のうち, 骨䯣炎 の 37 例と, 関節炎の 12 例である.

骨䯣炎は, その発症の形態を, 次の 3 つに分類した。 1 血行性, 2 医原性(術後感染), 3 外傷性, さらに血
行性を, 急性型, 覀急性型, 慢性型に分けた。なお， 骨髄炎の再燃例は，すべて慢性型に含めた。

関節炎の発症形態も，1血行性，2医原性（術後感 染, 注射を含む), 3 外傷性に分けた。

そして，骨髄炎においては，この発症形態別に起炎 菌を分類し，また，この発症の形態が，年次別に，ど う変わっているかを調べた。次に, 骨蹃炎の発症部位 と発症の形態との関連を調査した。

化膿性関節炎に扔いても同様に起炎菌の分類と年次 推移を調べた。

\section{結果}

\section{1. 骨髄炎るおける起炎菌}

骨髄炎の 37 例中起炎菌が検出されたのは, 25 例, 28 株であった.内訳は, グラム陽性球菌が 18 株, グラム 陰性桿菌が 10 株でグラム陽性球菌が多かった.グラム 陽性球菌の中では, 黄色ブ菌は最多の 14 株であった。

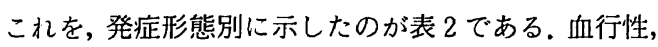


表 1 当科入院症例に扔ける感染症の内訳

\begin{tabular}{|c|c|c|c|c|c|c|c|c|}
\hline \multirow{2}{*}{ 年 度 } & \multirow{2}{*}{ 入院腎者数 } & \multicolumn{2}{|c|}{ 感染 症 } & \multicolumn{5}{|c|}{ 非 結 核 性 の 内 訳 } \\
\hline & & 非絬核性 & 結 核 性 & 骨䯠 炎 & 化㘚性関節炎 & 蜂窩織炎及び膿瘍 & ガス壊疸 & その他 \\
\hline 52 & 337 & 5 & 3 & 3 & 1 & 0 & 1 & 0 \\
\hline 53 & 368 & 9 & 1 & 8 & 0 & 1 & 0 & 0 \\
\hline 54 & 330 & 5 & 1 & 4 & 0 & 0 & 1 & 0 \\
\hline 55 & 399 & 7 & 2 & 5 & 1 & 0 & 0 & 1 \\
\hline 56 & 422 & 7 & 4 & 4 & 3 & 0 & 0 & 0 \\
\hline 57 & 442 & 3 & 2 & 2 & 1 & 0 & 0 & 0 \\
\hline 58 & 431 & 5 & 1 & 2 & 2 & 1 & 0 & 0 \\
\hline 59 & 427 & 12 & 1 & 8 & 1 & 1 & 1 & 1 \\
\hline $60^{*}$ & 216 & 5 & 2 & 1 & 3 & 1 & 0 & 0 \\
\hline 総 計 & 3372 & $\begin{array}{c}58 \\
(1.7 \%)\end{array}$ & $\begin{array}{c}17 \\
(0.5 \%)\end{array}$ & 37 & 12 & 4 & 3 & 2 \\
\hline
\end{tabular}

表 2 崩能炎ひ起炎阒

\begin{tabular}{|c|c|c|c|c|}
\hline & 炎 菌 & 血行性 & $\begin{array}{c}\text { 医原性 } \\
\text { (術後感染) }\end{array}$ & 外傷性 \\
\hline $\begin{array}{l}ク ゙ \\
ラ\end{array}$ & $\begin{array}{l}\text { Staphylococcus } \\
\text { aureus }\end{array}$ & 8 & 3 & 3 \\
\hline 㸞 & $\begin{array}{l}\text { Staphylococcus } \\
\text { epidermidis }\end{array}$ & 1 & & 2 \\
\hline 洅 & Streptococcus & 1 & & \\
\hline & E. coli & & 1 & \\
\hline भ & Citrobacter & 1 & & \\
\hline ラ & Klebsiella & 1 & & \\
\hline 公 & Enterobacter & & 1 & \\
\hline 性: & Serratia & 1 & & \\
\hline 葴 & Proteus & 1 & & 2 \\
\hline & $\begin{array}{l}\text { Pseudomonas } \\
\text { aeruginosa }\end{array}$ & 1 & & 1 \\
\hline & 过足走ごきず & 6 & 3 & 3 \\
\hline
\end{tabular}

医原性，外傷性ともに，黄色ブ菌がもっとも多かった。

2. 骨髄炎に扔ける発症形態の年次推移

骨髄炎の発症形態を, 急性型, 亚急性型, 慢性型の 3つに分けた。亜急性の診断は，Harris.の方法にした
表 3 血行性骨髄炎の発症形態の年次推移

\begin{tabular}{c|c|c|c|c}
\hline \hline 年度 & 急性 & 亜急性 & 慢性 & 計 \\
\hline 52 & & 1 & & 1 \\
\hline 53 & 1 & 2 & 5 & 8 \\
\hline 54 & 1 & & 1 & 2 \\
\hline 55 & 1 & & 1 & 2 \\
\hline 56 & & & & 0 \\
\hline 57 & & 1 & & 1 \\
\hline 58 & & & & 0 \\
\hline 59 & & 2 & 1 & 3 \\
\hline 60 & & & 1 & 1 \\
\hline
\end{tabular}

がった。これらの発症形態の年次推移をみると, 表 3 に示すごとく，急性型を示したのは 3 例のみで，いづ れも昭和 55 年以前に発症したものであった。一方亜急 性型と, 慢性型の発症の年次推移には, 一定の傾向は みられなかった。

3. 骨髄炎の発症形態と部位

血行性発症では，骨幹端が多かった。一方，外傷性， 医原性においては，骨幹端ばかりではなく骨幹にも発 症しているが，これは，発症のメカニズムからすれば 
表 4 骨髄炎の部位と発症形態

\begin{tabular}{|c|c|c|c|c|c|c|c|c|c|c|}
\hline & \multicolumn{2}{|c|}{ 上腕 骨 } & \multirow{2}{*}{ 脊 椎 } & \multicolumn{2}{|c|}{ 大 腿 骨 } & \multicolumn{2}{|c|}{ 脛骨 } & \multirow{2}{*}{ 足根骨 } & \multirow{2}{*}{ 中足骨 } & \multirow{2}{*}{ 不 明 } \\
\hline & 骨 幹 & 骨幹端 & & 骨 幹 & ，骨幹端 & 骨 幹 & 骨幹端 & & & \\
\hline 血 行 性 & 1 & 1 & 1 & 2 & 7 & 2 & 4 & 1 & 1 & \\
\hline 外 傷 性 & & 1 & & 1 & 1 & 2 & 1 & 3 & 1 & 1 \\
\hline $\begin{array}{c}\text { 医 原 性 } \\
\text { (術後感染) }\end{array}$ & 1 & 1 & & 3 & 1 & 1 & & & & \\
\hline
\end{tabular}

表 5 化膿性関節炎の起炎菌と発症形態

\begin{tabular}{|c|c|c|c|c|}
\hline \multicolumn{2}{|r|}{ 起 炎 菌 } & 血行性 & $\begin{array}{l}\text { 医原性 } \\
\text { (術後感染) }\end{array}$ & 外傷性 \\
\hline \multirow{3}{*}{$\begin{array}{l}\text { グ } \\
\text { ラ } \\
\text { 㕕 } \\
\text { 愓 } \\
\text { 球 } \\
\text { 囷 }\end{array}$} & $\begin{array}{l}\text { Staphylococcus } \\
\text { aureus }\end{array}$ & & 2 & \\
\hline & $\begin{array}{l}\text { Staphylococcus } \\
\text { epidermidis }\end{array}$ & & 1 & \\
\hline & Streptococcus & 1 & 1 & \\
\hline \multirow{7}{*}{$\begin{array}{l}\text { グ } \\
\text { ラ } \\
\text { ム } \\
\text { 陰 } \\
\text { 性 } \\
\text { 桿 } \\
\text { 菌 }\end{array}$} & E. coli & & & \\
\hline & Citrobacter & & & \\
\hline & Klebsiella & & & \\
\hline & Enterobacter & & & \\
\hline & Serratia & & & \\
\hline & Proteus & & & \\
\hline & $\begin{array}{l}\text { Pseudomonas } \\
\text { aeruginosa }\end{array}$ & & 1 & \\
\hline \multicolumn{2}{|r|}{ 同定できず } & 1 & 5 & \\
\hline
\end{tabular}

当然のことといえる。

\section{4. 化膿性関節炎の起炎菌}

化膿性関節炎の発症形態は, 血行性が 2 例, 医原性 が 10 例, 外傷性はみられなかった. 血行性の 2 例中 1 例, 医原性 12 例中の 5 例に起炎菌の検出が可能であっ た。これらにおいても，グラム陽性球菌が 5 例で最多 であった.

\section{5. 化膿性関節炎の年次推移}

発症形態が血行性のものに関しては, 症例数が少い ために，年次推移に関して云々することはできなかっ た。医原性では，最近の数年においては，よくその発 生がみられており，これらの中には，かならず関節
表 6 化膿性関節炎の年次推移

\begin{tabular}{c|c|c|c}
\hline \hline & 血行性 & 医原性 & 外㑺性 \\
\hline 52 & & $1(1)$ & \\
\hline 53 & & & \\
\hline 54 & & & \\
\hline 55 & 1 & $3(1)$ & \\
\hline 56 & & & \\
\hline 57 & 1 & $1(1)$ & \\
\hline 58 & & $3(2)$ & \\
\hline 59 & & $(\quad)$ (小は注射によるも0
\end{tabular}

腔内ステロイド剤の注入に起因するものが含まれてい た.その他の原因として, 人工関節術後の感染が 3 例 含まれていた.

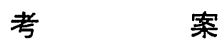

起炎菌の変遷については, 林 ${ }^{21}$, 長谷川 ${ }^{3)}$, 長野4) など の研究があり，それらによれば年次が進むにしたがっ て, グラム陰性桿菌の検出が増大しているが, しかし, 頻度からいえば黄色ブ菌が，もっとも高い. われわれ の症例においても, 骨髄炎, 化膿性関節炎, いゔれの 起炎菌も, 黄色ブ菌が, ほとんどであって, グラム陰 性桿菌が，最近とくに増えてきたという所見は得られ なかった。これらの菌の抗生物質に対する感受性は, その判定法が，昭和 55 年で変わったために，今回は， 調查することができなかったが, 昭和 60 年に下腿開放 性骨折術後感染には, 多剤耐性の菌がみられた。 
骨䚙炎の発症形態は，従来の教科書的な急性型発症 は，減りつつあることは事実であり，逆に, Harris ${ }^{1)}$ 指摘しているごとく, 亜急性発症の増加が, 本シリー ズでもみられた。これら垔急性型は，彼によれば，特 徵的なX線像を呈するとしているが, 自験例の中には, 骨腫演との鑑別に苦労した症例もあった，しかし今後 の骨髄炎の臨床的X線学的病態は，いわゆる亜急性あ るいは慢性のかたちをとることが予想されるので，そ のことの認識が重要であると考える。

骨関節感染症の発症形態として骨髄炎は, 外傷性あ るいは医原性もけっして少くはないし，化膿性関節炎 に至っては，医原性が，ほとんどを占めている。これ らは，診療する側の適切な処置によって防ぎ得るもの と考えられるが, とくに, 膝関節注入後の感染は, か えって増加していると思われる. 以上のごとく, 当科 に扔ける 9 年間の感染症における特徵的なことは，亜 急性型や慢性型で発症する骨髄炎が多くなってきたこ と, 発症の原因として術後感染や, 膝関節穿刺に伴う 医原性感染が多いことなどをあげることができる。こ れらのことは感染症の予防診断治療において一つの示 唆を与えてくれるものと考える.

$$
\text { ま と め }
$$

感染症の病態の変遷を知る目的で, 昭和 52 年 2 月か
ら, 昭和 60 年 7 月までの間に, 当科に入院した化膿性 関節炎と骨䯣炎の実態を調査した。骨䯣炎 37 例, 化膿 性関節炎の 12 例において起炎菌は, 黄色ブ菌がもっと も多かった。骨髄炎の発症形態は, 亜急性, または慢 性の型をとるものが増えていることがわかった。化膿 性関節炎においては，膝関節穿刺による感染が増加し てくる傾向がみられた。

以上のことから，骨髄炎の診断において，亜急性型 や慢性型の存在の認識, および，医原性感染症の発症 防止に対する啓蒙が重要であると思われた。

\section{文献}

1) Harris, N. H: Primary subacute pyogenic osteomyelitis, J. Bone and Joint Surg., 47-B : 526$532,1965$.

2）長谷川弥人：感染症の変遷. 治療, $57: 1937-1944$, 1975.

3) 林浩一郎：筑波大学付属病院開院以来の検出菌 4,099 菌の分析. 整・災外, $23: 849-854,1980$.

4) 長野 昭：創と細菌. 整形外科, $26: 175-181,1975$.

5）下山議七郎：われわれが経験した原発性骨髄炎とく に原発性慢性骨髄炎について。整・災外, $23: 855-863$, 1980. 